\title{
States, Security Function and the New Global Forces
}


Paper presented at the REGIS sponsored Conference on "What States Can do N ow", M cGill U niversity, M ontreal, N ovember 3-4, 2000.

D esign, Zéro faute, O utremont

ISBN 2-922249-09-3

D épôt légal-Bibliothèque nationale du Q uébec, 2001

$D$ épôt légal-Bibliothèque nationale du $C$ anada 
T.V. Paul is Professor of Political Science at McGill U niversity, $M$ ontreal, Canada. He also serves as Director of the U niversity of M ontreal-M cGill Research Group in International Security (REGIS). Paul specializes and teaches courses in international relations, especially international security, international conflict \& conflict resolution, regional security and South $\mathrm{Asia}$. $\mathrm{He}$ received his undergraduate education in India, and MA and Ph.D. in Political Science from the U niversity of California, L os Angeles. Paul is the author of the books: Power versus Prudence: Why $\mathrm{N}$ ati ons Forgo $\mathrm{N}$ uclear Weapons ( $\mathrm{M} \mathrm{CG}$ illQ ueen's U niversity Press, 2000); A symmetric C onflicts. War I nitiation by Weaker Powers (Cambridge U niversity Press, 1994), and co-editor and contributor to the volumes: International Order and the Future of World Politics (with John A. H all, Cambridge U niversity Press, 1999 \& 2000) and The A bsolute Weapon R evisited: N uclear Arms and the Emerging I nternational Order (with J ames Wirtz and Richard $\mathrm{H}$ arknett, The U niversity of M ichigan Press, 1998 \& 2000). During 1997-98, he was a Visiting Scholar at $\mathrm{H}$ arvard U niversity's Center for International Affairs (CFIA) and the O lin Institute for Strategic Studies. $\mathrm{He}$ is currently working on the book projects: The $\mathrm{N}$ ation State U nder Challenge: A utonomy and Capacity in a Changing World (with G. John I kenberry and John A. H all), The World Order and India: Challenge and Integration in the Major Power System (with Baldev Raj $\mathrm{N}$ ayar) and Transitions without War: Grand Strategies of Peaceful Change in the International System. D uring 1995-98 he served as the Assistant Editor of Canadian Journal of Political Science. 
Notes de recherche du GERSI/REGIS Working Papers

Collection dirigée par/Series Editors

T.V. Paul • Michel Fortmann

1. Zartman, I. William, «The Structuralist Dilemma in Negotiation» (1997).

2. LeBow, Richard Ned, «Transitions and Transformations: Building International Cooperation » (1997).

3. BUnCE, Valerie, "The collapse of Socialism, the Soviet Bloc and Socialist States: An Institutionnal Account » (1998).

4. Roussel, Stéphane, Gervals, M yriam et Ronald Hatto, «Chronologie de la réaction du $C$ anada face aux conflits intra-étatiques vol. 1 : I'ex-Yougoslavie» (1998).

5. Roussel, Stéphane, Gervais, M yriam et Ronald H atto, "Chronologie de la réaction du $C$ anada face aux conflits intra-étatiques vol. 2 : I'Afrique des Grands L acs (Rwanda et Est-Zaïre)» (1998).

6. GAGNON, Rémy, "Les théories de l'émancipation et l'étude de la sécurité internationale: entre le rationalisme et le réflexivisme» (1999).

7. TESSIER, M anon, « Guide pratique de la recherche sur le maintien de la paix sur Internet » (2000).

8. Joliceur, Pierre, «L'identité civilisationnelle: un concept utile pour l'analyse des conflits caucasiens?» (2000).

9. KuBÁLKOVÁ, Vendulka, "The tale of two constructivisms at the cold war's end »(2001). 


\title{
States, Security Function and the New Global Forces
}

\author{
T.V. PAUL
}

In this paper, I explore the impact of globalization on one of the fundamental functions of nation-states-national security. Contrary to the polar positions of the proponents and the opponents of globalization, I argue that national security still remains a core function of the nation-state, but the extent of security behavior varies depending on the particular situations of states. Largely under the influence of systemic changes propelled by the end of the Cold War, rapid technological changes in both the civilian and military spheres, and the resurgence of the American hegemonic power, the nature of security competition has altered somewhat, but it is premature to bury the nation-state or its role as the key provider of national security.

The paper critiques the contention that, because war created nationstates, the end of warfare could result in citizens losing their identities based on citizenship and their loyalties to the state. I argue that geopolitical competition is unlikely to simply become an issue of the past, even though increasingly other forms of competition-geoeconomic, geo-technological-may occur and these competitions may sometimes compensate for active military rival ries for a period of time. Systemic forces are still at work, and over time the rise of new major powers and the decline of the present ones will affect the contours of world politics and state behavior. The paper also briefly looks at the $U$ nited States and its role as the security provider in the new era. 
I argue that the US is unlikely to loosen its role as a national security state. The U nited States will face both hard and soft challenges to its security given its extant position as the hegemonic power, and because of this, it is bound to be involved in limited conflicts with smaller powers and large-scale competition with other great powers, especially China and Russia. Although war in the great power system is unlikely, war preparation is likely to be actively present in it because of the fear that losing out in the technological revolution for new arms may create opportunities and willingness for the great power that gains an advantage in the competition. States, especially the major powers, will choose allies and partners on the basis of congruence of interests in the security sphere. The increasing unilateralism of the U S and pressures emanating from the desire of other key states for multipolarity will result in the continuation of soft challenges, including technological competitions involving the US and other developed states, especially those in Europe.

In the following pages, I explore the impact of globalization on the state, especially the $U \mathrm{~S}$, as the national security provider. I make several inter-related arguments. First, globalization, despite its wide sweep, is to a certain extent, although not exclusively, the "Americanization" of economic, political and cultural ideas and practices. Second, globalization by no means has ended power competition among the major powers. Limited peace caused by the decline and subsequent domination of one or another major power is not a precursor to lasting or perpetual peace. Efforts to convert hegemony into empire are unlikely to succeed; while benign policies might produce benign results, these may not last indefinitely. Third, the relative gains problem does exist even when multiple global channels and networks link countries. As long as nations gain economic benefits fairly uniformly, competition is likely to remain limited, or even muted, but once large-scale inequalities creep in, states that lose out may resort to challenge by means other than exerting voice from within or even 'exit' if they are capable of doing so. Fourth, hegemony by its very nature creates counter-pressures on those who are most affected by it. Those who can mobilize against the hegemon may well do so, often through asymmetrical means and strategies. Attempts by the hegemonic state to adjust to its decline may also produce challenge and opposition. As long as the hegemonic state is in a dominant position and it can offer collective goods to others, be they security or market access, large-scale disturbances are unlikely to occur. H owever, 
in order for the hegemon to prolong its power position, it has to innovate constantly and ward off potential threats from weaker actors. Such innovation forces others to catch up through arms races or asymmetric strategies that limit the extent of the hegemon's innovative edge. Continued dominance by a single actor creates insecurities for subordinate states and these may manifest themselves in actions that appear 'rogue', while the hegemon may make responses that are "hyper" or are based on "technological fixes."

\section{Contending Views on Globalization and the State}

Globalization enthusiasts have argued that "hard geopolitics" has become obsolete, partly due to the lethality of new weapons and partly because states are now more interested in wealth acquisition through economic liberalization and trade. ${ }^{1}$ To them, war-making is no longer the state's primary focus, given the dramatic decline of inter-state wars since the end of the Cold War in 1991. In the larger international arena, great power competition is conducted through "soft geopolitics," with less emphasis on overt competition, arms buildup or crisis activity. ${ }^{2}$

1. Different versions of the globalization thesis exist in the literature. Extreme proponents like O hmae contend that under the irreversible influence of modern information technology, genuinely borderless economies are emerging, affecting values and behavior of citizens around the world. Kenichi O hmae, The End of the N ation Sate, New York: Free Press, 1995:vii. M ore nuanced versions of this theme are presented by James $N$. R osenau, "N ew D imensions of Security: The Interaction of Globalizing and Localizing Dynamics," Security Dialogue, 25(3) 1994:255-81; T ony Spybey, Globalization and World Society, Cambridge, Polity Press, 1996; $\mathrm{H}$ ans-H enrik $\mathrm{H}$ olm and George Sorensen, Whose World Order? U neven Globalization and the End of the Cold War, Boulder: Westview Press, 1995; David Held et al. Global Transformations. Politics, Economics and Culture, Stanford: Stanford U niversity Press, 1999.

2. Mann, although not a proponent himself, summarizes the position of the globalists in this respect: "Post-nuclearism undermines state sovereignty and 'hard geopolitics,' since mass mobilization warfare underpinned much of modern state expansion yet it is now irrational." M ichael M ann, "H as Globalization Ended the Rise and Rise of the Nation-state?" in T.V. Paul and John A. $\mathrm{H}$ all, eds. International Order and the Future of world Politics, Cambridge: C ambridge U niversity Press, 1999:238. G lobalists in general believe that social relations worldwide have increased with events happening in different locations affecting each other while the "locus of power gradually shifts in varying proportions above and below the territorial state." James H. M ittelman, The Globalization Syndrome: Transformation and R esistance, Princeton: 
To some, non-traditional issues such as terrorism, organized crime, drug trafficking, ethnic conflicts, exploding population growth, environmental degradation, and mass poverty have emerged as the key security threats. Competing notions of 'human security' have begun to make inroads into official thinking in various countries "suggesting that security be viewed as emerging from the conditions of daily life-food, shelter, employment, health, public safety-rather than flowing downward from a country's foreign relations and military strength." 3 For instance, James Rosenau contends that the nationstate has weakened as a result of global social forces. To him, in political, social and economic realms, fragmentation has occurred and as a result "the close links between territoriality and the state are breaking down.... In the political realm... authority is simultaneously being relocated upward toward supranational entities, sideward toward transnational organizations and social movements, and downwards toward sub-national groups and communities.... These shifting tendencies are diminishing the competence and effectiveness of states and rendering their borders more porous and less meaningful." The salience of internal issues, in turn, has decreased the importance of the state as the national security provider, whereas security has traditionally been the core function of the nation-state, endowing it with legitimacy and societal power. ${ }^{4}$

From the perspective of globalists, nations cannot afford to engage in large-scale warfare any longer, chiefly due to deepened economic

Princeton U niversity Press, 2000:6; see also Anthony Giddens, The Conse quences of Modernity, C ambridge: Polity Press, 1990:64.

3. Jessica M athews, "Power Shift," Foreign Affairs, 76(1), January/ February 1997:51. Cha summarizes some of the changes that globalists have presented. First, "an inter-penetration of foreign and domestic issues such as that national governments increasingly operate in spaces defined by the intersection of internal and external security. Second, globalization puts unprecedented bureaucratic innovation pressures on governments in their search for security, and creates multilateralist pressures to cooperate with substate and transnational partners rather than traditional allies. Third, globalization makes the calculation of relative capabilities extremely complex and nonlinear. Finally, globalization compels contemplation of new modes of fighting as well as renders accepted modes of strategic thinking and rational deterrence increasingly irrelevant." Victor D. Cha, "Globalization and the Study of International Security," J ournal of Peace R esearch, 37(3), 2000:391-403.

4. K.J. Holsti, The State, War, and the State of War, Cambridge: Cambridge U niversity Press, 1996. 
interdependence and multi-layered interactions among states and among transnational actors such as business corporations. M ore and more businesses are moving away from multinational to transnational levels of operation, i.e., producing components in different countries worldwide and assembling them in others. Such production methods have made individual subsidiaries "practically unable to produce anything if cut off from the rest of the company. In many developed countries, businesses integrated transnationally now account for onethird to one-half of the industry's output." ${ }^{5}$ War under these circumstances would mean high economic costs for all states concerned, and therefore it is only rational for interdependent states to forgo armed conflict as a mechanism to resolve interstate disputes.

Furthermore, as more and more countries choose democratic governance, the argument goes, the liberalizing elites deliberately undermine the power of their militaries and thereby decrease the role of the national security elite and its concerns in state policies. As the liberalizing elites seek foreign capital and investment as well as regional free-trade arrangements, they need to cut defense spending, reduce the size of the armed forces, and conclude regional cooperative security arrangements. ${ }^{6}$ Such reductions are also necessary in order to gain capital and investment from international financial institutions and market access to powerful economies such as that of the $U$ nited States. ${ }^{7} \mathrm{M}$ oreover, according to liberals, democracies rarely fight each other, and the widespread democratization of countries has reduced the propensity of states to use force against one another. D emocracies deliberately play down military threats since they are reassured by the benign intentions of their democratic counterparts. There are both

5. Peter F. Drucker, "The Global Economy and the Nation-State," Foreign A ffairs, 76(5), September-O ctober 1997:170-71. Echoing these positions, Zacher contends that states are "becoming increasingly enmeshed in a network of interdependencies and regulatory/ collaborative arrangements from which exit is generally not a feasible option." M ark W. Zacher, "The D ecaying Pillars of the Westphalian Temple: Implications for International O rder and Governance," in James N. Rosenau and Ernst-Otto Czempiel, eds., Governance without Government: Order and Change in World Politics, Cambridge: Cambridge U niversity Press, 1992:60.

6. Etel Solingen, Regional Orders at Century's Dawn, Princeton: Princeton U niversity Press, 1998:46.

7. The tension between the modern forces of globalization and the traditional forces of territory, culture, and glory are captured in Thomas Friedman, The Lexus and the Olive Tree, N ew York: Farrar Starus \& Giroux, 1999. 
institutional-structural and normative reasons for the restraint that democracies show towards one another. Democratic institutions constrain states as they make it harder to respond militarily to other democracies in times of crises. Democracies also externalize their domestic political norms of tolerance and compromise in their foreign relations. ${ }^{8}$

More importantly, some believe that as threats decrease, the security function of the state declines and, as a result, the attachment of citizens to their state declines as well. Nation-states, founded on the principle of protection to the citizenry as its core function, have trouble developing an alternative to war as a source of loyalty; which is often shown as the ultimate willingness of the citizen to sacrifice his/ her life for the defense of the country. ${ }^{9}$ The decline in the traditional national security function of the state may also result in the weakening of states as divisive forces within step up their struggle over the basic principles of domestic order. ${ }^{10}$

$\mathrm{H}$ owever, the liberal and globalist views have not gone unchallenged. Indeed, the proponents of neorealism have argued that the security function of the state has increased and that the new global forces that are supposedly undermining states and their functions in the security arena are exaggerated. To them, with the end of the Cold War, the glue that held the international system together, the bipolar structure, has disintegrated and that this will eventually force countries to seek autonomous military capabilities. It is only a

8. M ichael Doyle, "Liberalism and World Politics," A merican Political Science R eview, 80(4), D ecember 1986:1151-69; Bruce Russett, Grasping the D emocratic Peace, Princeton: Princeton U niversity Press, 1993; Steve Chan, "In Search of D emocratic Peace: Problems and Promises, "M ershon International Studies R eview, 41:1997:59-85.

9. The strongest proponent of this viewpoint has been Lipschutz, who argues: "Loyalty to the state has been replaced by loyalty to the self, and national authority has been shouldered aside by self-interest. The world in the future might not be 200 or 500 or even 1,000 (semi-) sovereign states co-existing uneasily; it could well be one in which every individual is a state of her own, a world of 10 billion stateless, living in a true State of N ature." Ronnie D. Lipschutz, After A uthority: War, Peace, and Global Politics in the 21st Century, Albany: State U niversity of N ew York Press, 2000:5. A more modest version of this argument can be seen in M ichael C. D esch, "War and Strong States, Peace and Weak States?" International Organization, 50(2), Spring 1996:237-68.

10. D aniel Deudney and G. J ohn I kenberry, "After the Long War," Foreign Policy, 94, Spring 1994:21-35. 
matter of time, in this view, when formerly dependent countries, such as J apan and Germany, will seek greater international roles by acquiring the military wherewithal, including nuclear weapons, commensurate with their economic prowess. ${ }^{11}$ Some neo-classical realists also argue that security competition does not change from age to age and that "bad times return." For instance, Colin Gray, paraphrasing Clausewitz, argues that "war is a chameleon-able to adapt to new circumstances effortlessly." 12

Contrary to these polar positions, I argue that as we begin the $21^{\text {st }}$ century the picture in respect to the state's security function is a mixed one. $\mathrm{N}$ either the optimism of the globalists nor the pessimism of the proponents of military security-first approaches is fully warranted. Similar predictions in the past of the demise of the nation state, as well as the decline of the state's security function-in the face of the advent of nuclear weapons and growing economic interdependencehave been short lived. ${ }^{13}$ Following brief episodes of inter-state

11. Waltz argues: "Economic competition is often as keen as military competition, and since nuclear weapons limit the use of force among great powers at the strategic level, we may expect economic and technological competition among them to become more intense.... For a country to choose not to become a great power is a structural anomaly. For that reason the choice is a difficult one to sustain. Sooner or later, usually sooner, the international status of countries has risen in step with their material resources. Countries with great power economies have become great powers, whether or not reluctantly." Kenneth N. Waltz, "The Emerging Structure of International Politics," International Security, 18(2), Fall 1993:66; Waltz, "Globalization and American Power," The N ational Interest, Spring 2000:46-56. See also John J. M earsheimer, "Back to the Future: Instability in Europe after the Cold War," International Security, 15(1), Summer 1990:5-56; and Christopher Layne, "The U nipolar Illusion: Why N ew Great Powers Will Rise," International Security, 17(4), Spring 1993:5-51.

12. Gray adds: "War's nature as organized violence for political goals survives untouched by radical shifts in political forms, motives for conflict, or technology." To Gray, no "endist transformational theory" is in sight to slay strategic history. Colin Gray, "Clausewitz Rules, O k? The Future is the Pastwith GPS," Review of International Studies, 25, December 1999:169. See also Gray, Modern Strategy, Oxford: Oxford U niversity Press, 1999:9-11, 362-64.

13. John H . H erz, "The Territorial State Revisited: Reflections on the Future of the $\mathrm{N}$ ation State," in James $\mathrm{N}$. Rosenau, International Politics and Foreign Policy: A Reader in Research and Theory, $\mathrm{N}$ ew York: The Free Press, 1969:76-77; See also Herz, "Rise and Demise of the Territorial State," World Politics, 9, 1957:473; Klaus Knorr, On the U ses of Military Power in the N uclear A ge, Princeton: Princeton U niversity Press, 1966; Robert 0. 
cooperation, states bounced back as national security actors as the empirical reality of their independent role in security and security competition began to set in. Yet the manner in which states conduct military competition and war has changed in our times, a point that neo-realists and neo-classical realists fail to adequately take into account. Especially noteworthy in this connection is the virtual absence of warfare among the major powers and among the established democracies. Noticeable changes are also visible in the functions, attitudes and threat assessments of the militaries across the world. ${ }^{14}$

$\mathrm{M} y$ argument is that variations exist in the realm of security and state responses to challenges posed by globalization, but they are uneven and not so profound as globalists argue, and not so trivial as realists characterize them. I contend that in order to explain the variations we need to look at the political, economic and security contexts of different states. These contexts cut across both domestic and international levels. To a great extent, the distribution of power determines systemic and sub-systemic level variations while domestic level factors revolve around state strength and the political characteristics of the states concerned. Variations also exist in the behavior of middle and small powers that have great power protection or whose regions have developed institutions to manage or contain inter-state conflict.

The argument is that great power conflict has subsided since the end of the Cold War, but the system leaders are conducting their competition through technological innovations in armaments, of both offensive and defensive varieties, and creation of new balance of

Keohane and Joseph S. N ye J r., "Power and Interdependence Revisited," International Organization, 41(4), Autumn 1987:727.

14. M oskos calls the new situation a "post-modern military paradigm." According to him, the new paradigm consists of several variables and they are most relevant in the U S case. For instance, the primary perceived threat during the Cold War was nuclear war, which has now changed to subnational conflicts. The force structure was a large professional army, which is now a small professional army. The major mission was to support alliance partners whereas the new missions include peacekeeping and humanitarian assistance. The public attitude towards the military used to be ambivalence, which now has become indifference. $O$ ther changes are visible in the areas of media relations, and the role of civilian employees, women, spouses, homosexuals and the possibility for conscientious objection. Charles C. M oskos, "Toward a Post-modern M ilitary: the U nited States as a Paradigm," in M oskos, John Allen Williams and D avid R. Segal, eds., The Postmodern Military: A rmed Forces after the Cold War, New York: Oxford U niversity Press, 200:15. 
power alignments. The great power system has not witnessed any dramatic decrease in military spending (barring that of Russia) despite the cuts in the early 1990s. The U S, Russia and China have been engaging in new forms of arms races, this time focusing more on information warfare and "usable" mini nuclear weapons. Further, they have acted in unison to prevent the rise of new nuclear states and additional states acquiring delivery systems such as ballistic missiles, fearing that such diffusion of capabilities would undermine their dominance in the international system. M oreover, the "end of history" is not in sight with respect to a fundamental characteristic of the modern international system, i.e., power transitions resulting from the rise and fall of great powers. In fact, the international system is notorious for its lack of non-violent mechanisms to integrate rising economic and military powers or provide them with leadership roles without conflict. ${ }^{15}$

O $n$ a global scale, there has been no substantial relinquishing of armed forces by states despite the fact that some states have scaled down the size of their armed forces. O nly two small states, $\mathrm{H}$ aiti and Panama, have abandoned their armed forces and adopted the Costa Rica model. M oreover, many trading states in the world are big spenders on defense, belying the argument that the national security state has all but vanished in the face of the forces of globalization and economic liberalization. ${ }^{16}$ Furthermore, the contention that the increasing transactions among non-state actors and their assumption of the means of violence have fundamentally reduced the state's monopoly over force is not accurate. $\mathrm{H}$ istorically, non-state actors played significant roles along with states. As Bull contends, in eighteenth and nineteenth century Europe also states co-existed and shared the stage with chartered companies, revolutionary and counter-revolutionary political parties, and national liberation movements. ${ }^{17}$

15. On this, see Kalevi J. H olsti, Peace and War: A rmed Conflicts and International Order 1648-1989: Cambridge: Cambridge U niversity Press, 1991:339; Ronald L. Tammen et al., Power Transitions Strategies for the 21st century, N ew York: Chatham H ouse, 2000.

16. The 25 big defense spending nations include several trading as well as Western liberal states. The U S defense expenditure of $\$ 305.4$ billion is higher than the spending of all other 24 states combined. For these statistics, see Fact Sheet, Washington D.C.: Center for D efense Information, February 7, 2000.

17. H edley Bull, "The State's Positive Role in World Affairs," Daedalus, 108(4), Fall 1979:112. 
It is, however, wrong to argue that no change has occurred in the realm of the state's security functions as we enter the $21^{\text {st }}$ century. Despite bleak predictions by neo-realists and neo-classical realists, there is no strong evidence to suggest that, now that the Cold War is over, countries are rushing to acquire arms or adopt offensive military postures. In fact, during 1989-1998, world military expenditures declined by one-third (to $\$ 745$ billion in 1998) on an average of 4.5 per cent per year. H owever, this decrease has slowed down since 1998. ${ }^{18}$ Some nuclear or nuclear-threshold states, such as South Africa, Argentina, Brazil, U kraine, Kazakhstan and Belarus gave up their nuclear programs and aspirations, while several other technologically capable states are maintaining their non-nuclear policies. ${ }^{19}$ Especially important is the fact that Germany and Japan, two potential great powers, are maintaining their non-nuclear commitments. India and Pakistan, two states that declared themselves nuclear in 1998, al ready had their weapons developed in the 1980s while Israel, the third undeclared nuclear state, had developed its nuclear weapons capability in the 1970s; the programs of aspirants such as I raq, I ran, and N orth Korea predate the end of the Cold War.

$C$ hanges have also occurred in the nature of warfare as a result of the increasing salience of internal wars over inter-state warfare. M ilitaries, especially in the developed world, are increasingly focusing on the need to reduce casualties, especially of their own fighting forces and the enemy's civilian population. Because military actions in civil wars are more protective or peacekeeping in nature, there is all the more reason to focus on reducing casualties. H owever, this new style of warfare has not reduced the collateral effects on civilian populations in terms of "displacement, deprivation through sanctions, exposure and famine." $20 \mathrm{M}$ oreover, the U S and its allies have been increasingly using economic sanctions as a tool to achieve objectives that they

18. The decrease was most prominently manifest in Central and Eastern Europe, especially Russia and this was due to continued economic constraints experienced by these sates. Stockholm International Peace Research I nstitute, SI PR I Y ear Book, 1998. Oxford: Oxford U niversity Press, 1999:269-70.

19. T.V. Paul, Power versus Prudence Why N ationsForgo N uclear Weapons, M ontreal and Kingston: M CG ill-Q ueens' U niversity Press, 2000.

20. John Leech, "War without D eath: The Silent Strategies," Strategic R eview, 28(2), Spring 2000:19-27, 20. 
have failed to obtain through war. ${ }^{21}$ These sanctions, in instances like I raq, have had somewhat similar effects of slow carpet bombings, in terms of their devastating impact on the target state's economy and well-being of the population.

The responses of states to global social changes have not been uniform throughout the world. In some regions, states continue to pay more attention to the traditional national security function than in others. D espite incremental changes in regions like Latin America, the security function of states has not significantly declined in regions such as East and South Asia, Africa, the Persian Gulf and the M iddle East. In fact, in some of these regions, the security function has increased even among economically liberalizing states (e.g., India) and among those that have made regional security arrangements (e.g., Indonesia), especially in the area of domestic security. Although the European U nion has made defense cuts in the wake of the collapse of the Warsaw Pact, the key European states, U K, France and Germany, are in the process of strengthening their security ties through other means, such as the creation of the European Security and D efense I dentity (ESDI). These states, after participating in the US-led military operations in Kosovo in 1999, have concluded that they need to develop more autonomous defense capabilities in order to decrease their over-dependence on the U nited States. Some EU members also harbor an interest in the creation of a version of a $U$ nited States of Europe, and autonomous security behavior and capability are viewed as reinforcing that potentially unified entity. In East Asia, while C hina has increased defense spending, Taiwan has been on a weaponsbuying spree, and both the Koreas have increased their spending on defense. Japan, despite its four decades of a non-military focus, has changed course somewhat, with spending increases, participation in overseas peacekeeping operations, redefining SDF functions and, of late, it has given indications that it may amend Article 9 of the Constitution which forbids the militarization of J apan. ${ }^{22} \mathrm{H}$ owever, it

21. On the value of sanctions as a tool of statecraft, see Jean-M arc F. Blanchard and Norrin M. Ripsman, "Asking the Right Question: When do Economic Sanctions Work Best?" Security Studies, 9(1/2), Autumn 1999-Winter 2000:219-53.

22. According to one analysis, with a defense budget of $\$ 35$ billion, "Japan's defense spending exceeds that of both Russia and China. Tokyo has the second largest navy in Asia-behind the U nited States-a substantial standing army, and its technology is second to few. The military option is Japan's 
has also strengthened alliance ties with the U S, thereby ensuring that Tokyo's pursuit of security is not unilateral.

What explains the variations in state responses in the area of security in the face of changing global forces? Can we locate key explanations by focusing on international and regional level factors or domestic level political and economic forces? The international level factors include the end of the Cold War, changes in balance of power politics involving major powers, and technological revolutions that are occurring in the instruments of warfare. At the domestic level, does the continuing hold of the military in power and the "holy cow" nature of national security (or what Tilly calls the protection racket) have something to do with the continuation of security focus of states?23 The answer to these questions lies in the specific situations of the state, as the influence of such factors varies across different states with different contexts.

The situations of the different states can be illustrated by placing them in the following broad categories. The particular context of a state, arising from systemic and sub-systemic factors, has a great to do in explaining their national security behavior in the Post-Cold War era.

1. M ajor powers. U nder this broad category, we need to look at the $U$ nited States as the status quo power, Russia as the declining power, and China as the rising power. These states, despite holding leadership positions in global and regional institutions, are the least constrained by the norms of state behavior that downgrade national security. Global social and economic forces have made only a limited

for the taking, should it choose." "Asia's Future Centers on China and Japan's," Stratfor.com, Global Intelligence U pdate, December 22, 1999.

23. Tilly has argued that states often manufacture threats to pursue the security function. H e states: "governments' provision for protection, by this standard, often qualifies as racketeering. To the extent that the threats against which a given government protects its citizens are imaginary or are consequences of its own activities, the government has organized a protection racket. Since governments themselves commonly simulate, stimulate, or even fabricate threats of external war and since the repressive and extractive activities of governments often constitute the largest current threats to the livelihoods of their own citizens, many governments operate in essentially the same way as racketeers." Charles Tilly, "Warmaking and State Making as O rganized Crime," in Peter B. Evans, Dietrich Rueschemeyer and Theda Skocpol, eds., Bringing the State Back In, Cambridge: Cambridge U niversity Press, 1985:171. 
dent in the primacy they accord to the national security state. Despite the apparent lack of overt hostility, the major powers are engaged in continuing competition over arms innovation, technology and spheres of influence.

The major powers are by definition national security states, they are prone to engage in military behavior/ competition beyond their regions that gives them leadership roles internationally. They tend to possess global power projection capabilities, and are in the forefront of technological innovations that would facilitate the creation of such forces. M ajor powers acquire military capabilities not only for security reasons, i.e., defense of the homeland and allies, but also for purposes such as maintaining structural, compellent, and deterrent power against other great powers and smaller adversaries, in whose affairs they wish to intervene. Among the major powers, security behavior varies depending on whether they are status quo, declining, or rising powers. In the post-Cold War international system, the U nited States has emerged as the status quo power, Russia as the declining power, and $\mathrm{C}$ hina as the rising power in terms of their overall power attributes and dispositions. These structural situations have affected their approach towards security and the acquisition and maintenance of military power capabilities.

2. States that are heavily involved in regional organizations: $M$ embers of the European $U$ nion, which have already established a pluralistic security community, are one example. Others include ASEAN and M ercosur member states that have been forming nascent security communities. The states in these regions have entered or are entering into security interdependent relationships and have helped to avoid warfare among themselves for several decades. These states attempt to minimize the possibility of security competition while devising benign strategies vis-a-vis one another. Their military planning and preparations are largely based on most-probable threat assessments as opposed to worst-case assumptions. The protection provided by the U nited States has helped many of these states, especially in Europe, to pay less attention to national security. This aspect, however, could change over time, especially if the $U S$ reduces its commitment to Europe.

3. R egional states, which are engaged in enduring rivalries with one another and with the great powers. There are two types of states in this category. First are states under some security protection of the US (e.g., South Korea, Taiwan and Israel) and the second category 
consists of those states that enjoy no credible security protection from outside and are often targets of economic or military sanctions by the U nited States. India, Pakistan, N orth Korea, I ran, I raq, and Syria are prime examples of the latter category of states. Some of these states seek regional hegemony and some face great power intervention in their internal affairs. These states live in regional environments characterized by protracted conflicts and enduring rivalries. By definition, protracted conflicts are long-standing and are driven by intractable issues such as territory, ideology or identity, and conflict relationships among protagonists spill over into most spheres of inter-state interactions. They are also the targets of arms merchants as they often buy advanced weaponry. These states may be weak in terms of their capacity to influence their societies as they hold minimum "infrastructural power," although they may have strong "despotic power" in terms of the strength of their armed forces in their regional environments. They are thus strong in some attributes of state capacity, but weak in others relating to societal capacity. Their military planning and preparations are based on worst-case assumptions as opposed to most-probable threat assessments.

4. Very weak and failed states M ostly in Africa, these states have failed to create state structures sufficient to provide security or economic protection to their citizens. M any such states are beset with problems of internal conflict driven by ethnic rivalries and political and economic inefficiencies. The state institutions often lack legitimacy and state laws receive little compliance from citizens. The capacity of states to protect citizens from predators is also minimal. H owever, overtime some such states have created military institutions and have increased their external conflict behavior. African states such as $\mathrm{C}$ ongo, $\mathrm{N}$ igeria and $U$ ganda fall under this category.

Category 1 and 3 states are the most concerned about the current and future revolutions in military affairs (RM As), especially developments in information warfare and national defense and theater defense systems. Their concerns, however, vary depending on whether they are allies or adversaries of the leading global power, the $U$ nited States.

The remaining section of the paper will largely discuss the responses of the $U$ nited States in the security arena in reaction to the forces of globalization. In that context, the positions of Russia, China and some key smaller challengers to the U S hegemony will also be discussed. The US case is important, as globalization is heavily shaped and 
influenced by the U S through its policies in international institutions and U S-based multinational corporations that are the engines of much of globalized economic activity. Globalization, if indeed a force that affects all states, should have had its most powerful impact on the U S national security behavior. The effect seems perverse or limited on U S security policy. It is, therefore, imperative to explain why the US is behaving in the security arena the way it does.

\section{Responses by the United States}

Of all the states in today's international system, the US is probably the major beneficiary of economic globalization, as American-based multinational corporations have been its main engine. The $U$ nited States is the winner of the Cold War, and there is a sense in many quarters of the $U \mathrm{~S}$ establishment of the arrival of the unipolar moment. The new global social forces that globalists talk about should have had significant impact on this state. Yet, the US has been most prominent in the development of information warfare and missile-based defense systems. Its defense budget of nearly $\$ 300$ billion is almost 40 per cent of the world's total military expenditures and higher than the combined budgets of the other 24 leading defense spenders, including Russia, China and Japan. The national security function of the American state has shown no substantial decline from the Cold War days. ${ }^{24}$ The reasons that have been presented for this phenomenon relate to both the international and domestic levels.

For instance, Donald Snow argues that the culprit lies in domestic level factors. To him, the chief reason for the high defense spending are "the inherent conservatism of military planners and practitioners" whose planning is based on worst-case assumptions; "the intellectual and physical attachment to the Cold War," especially with respect to the vested interests developed as a result of the "virtually stationary adversary"; and the "lack of urgency in making

24. This does not mean that the overall size of the U S armed forces has not been reduced from the Cold War days. In fact, it has shrunk by 40 per cent or so from the Cold War peak in the 1980s. H owever, the military spending has not been reduced to the levels before the Reagan-era buildup. The US still spends over 80 percent of the military spending of the 1980s. This is poised to increase in the coming decades. Ann R. M arkusen and Sean S. Costigan, "The M ilitary Industrial Challenge," in M arkusen and Costigan, eds., Arming the Future: A Defense Industry for the 21st Century, New York: Council on Foreign Relations Press, 1999:12. 
military adjustments." 25 The domestic imperatives for high defense maintenance are also often attributed to partisan politics at both presidential and congressional levels. But do these domestic factors exclusively account for the persistence of high US spending?

I argue that domestic factors are important as proximate factors but that they arise from a larger systemic and structural context. The domestic consensus on military spending and technological innovation is the result of deeply embedded geopolitical factors and challenges to American hegemony that the US elite perceives from its vantage point. Although the US is not involved in any major military conflicts at the dawn of the $21^{\text {st }}$ century, the very fact that it is the global hegemonic power puts tremendous pressure on the American elite to maintain strong armed forces in the decades to come. Even though the "demands of war" have declined, the "demands for peace," as perceived by the elite, require high level of military preparedness. The bottom line is that the US elite wants to prolong the American hegemony as long as it can. The unprecedented economic prosperity of the 1990s has occurred in the backdrop of no serious armed conflict involving the major powers. The US consensus is not to allow any large or small power or combination of powers to challenge its dominance and, in order to do that, it ought to maintain its edge over others in military technology and the preparedness of its armed forces. $^{26}$

25. D onald M. Snow, The Shape of the Future, 3rd Edition, Armonk: N Y: M.E. Sharpe, 1999:96-97. According to Grieder, the American society is yet to come to terms with the end of the Cold War. The Cold War "provided a central purpose to the society," and "institutions of every kind accepted and adapted to the imperatives of the Cold War struggle.... The process has resembled a sophisticated form of log-rolling mutual trading and backscratching among states and companies and service branches.... The various political alliances refuse to give up on any of the military-industrial plans for the next round of fighter planes, ships, and missiles, despite the weakening rationale for them." William Greider, Fortress A merica: The A merican Military and the Consequences of Peace, N ew York: Public Affairs, 1998:xiv-xvii.

26. The U S strategic planning under the Clinton Administration has increasingly focused on a "preventive defense" strategy. According to proponents of the preventive defense approach, there are three types of national security threats to the US. The A-list threats are against the very survival of the state such as the Soviet threat during the Cold War. B-list threats-e.g. conflict in the Persian Gulf-are vital to US interests, but not for the survival of the country, while $\mathrm{C}$-list threats are those threats that indirectly affect U S security but not directly threaten US interests (e.g. Bosnia). Preventive defense is a com- 
The American hegemony is built around both military and economic power, but often globalists ignore the military dimensions of American power. This is partly because military power stays in the background and it is often hard to pinpoint its impact on economic, political and social forces. ${ }^{27}$ The U S navy and overseas-based forces continue to provide extended deterrent to allies and mount threats of intervention against smaller regional adversaries and rising powers, such as China. It controls the waters of all the strategically vital oceans and thus helps to keep the trade routes in the oceans open for shipping. Allies who would contribute men and money to its military efforts, if called for, also strengthen its support base overseas. The U S has also relied on regionalism and regional arrangements for both economic and political/ strategic purposes. ${ }^{28} \mathrm{M}$ uch of the global economic interactions among the Western states and their allies is occurring in the backdrop of this order built around American power, be it in Europe, East Asia, the M iddle East, Persian Gulf or Latin America.

The $U$ nited States has been the chief beneficiary of the postWorld War II international order, and in the post-Cold War era it has strengthened its primacy in both economic and military terms. The American decision-making elite, knowing that the unipolar moment is a passing phase, is attempting to establish and reinforce the rules of the game by creating and supporting a set of international

prehensive strategy which draws from political, military and economic instruments with the aim of preventing $B$ and $C$ lists threats that have the potential to grow into the A-list category, i.e. the survival of the $U$ nited States, in the next century. Ashton B. Carter and William J. Perry, Preventive D efense: A N ew Security Strategy for A merica, Washington D.C. Brookings Institution Press, 1999:14-18.

27. As Friedman puts it, global stability is sustained largely by the "presence of American power and the American willingness to use that power against those who would threaten the system of globalization.... The hidden hand of the market will never work without a hidden fist." The Lexus and the Olive Tree According to some, the U S has more or less succeeded in achieving the three objectives that it had laid out in the early 1990s: i.e., maintain the post- Cold War global balance of power, ensure American technological and military superiority, and create an economic climate favorable to its own interests. Thus, the U nited States has not withdrawn from global balance of power "in the free market utopia. O n the contrary, US hegemony and sovereignty have been strengthened in spectacular fashion." N oelle Burgi and Philip S. Golub, "H as Globalization Really Made Nations Redundant?" Le M onde Diplomatique, April 2000.

28. M ittelman, The Globalization Syndrome, 131. 
institutions, regimes and norms that would guarantee the non-arrival of a challenger in the foreseeable future. It sees (rather exaggeratedly) the spread of NBC (nuclear, biological and chemical) weapons and their delivery systems to dissatisfied regional states as undermining US hegemony and its capacity to intervene in the affairs of the regional states. These capabilities in the hands of minor actors could act as 'great equalizers' under certain circumstances. $\mathrm{H}$ owever, if proper counter-measures are taken, which include balancing and bandwagoning of regional states and the creation of prohibitory regimes and norms, the US believes it can remain the dominant actor in the international system for decades to come. Sanctions and technology denials are other means to keep recalcitrant states in their place and they are cheaper alternatives to war although their impact could be quite devastating on a target state (e.g., I raq since 1991 and Serbia since 1994).

The favorable developments associated with RMAs are especially critical to the U S perceptions of continuation of its hegemony. These revolutions are occurring in the spheres of information warfare, electronic warfare, precision guidance, remote guidance and control, and improvements in munitions, target identifications, and command, control and communication. ${ }^{29}$ The U S defense planners have discussed the challenges and opportunities posed by RM A technologies. For instance, the J oint Vision 2010 Report, prepared by former Chairman of the Joint Chiefs of Staff John Shalikashvili and the 1997 Q uadrennial D efense Review, prepared under D efense Secretary William Cohen, have called upon the US military to achieve "dominant battlefield knowledge," "full dimensional protection," "dominant maneuver," and "precision-strike ability for long-distance" in the first decade of the $21^{\text {st }}$ century. They called for the US to gain superiority in information technologies in areas of computers and electronic robotics, advanced munitions, ultra modern sensors, lighter, fuel efficient and stealth vehicles, ships and rockets, allowing rapid deployment capabilities, and space-based weapons and directed energy

29. Lawrence Freedman, "The Revolution in Strategic Affairs," A delphi Paper, 318, London: International Institute of Strategic Studies, 1998:21; Colin S. Gray, "Nuclear Weapons and the Revolution in Military Affairs," in T.V. Paul, Richard $\mathrm{H}$ arknett and J ames Wirtz, eds., The A bsolute Weapon R evisited: $\mathrm{N}$ uclear A rms and the Emerging International Order, Ann Arbor: The U niversity of Michigan Press, 1998:99-134. 
beams. ${ }^{30}$ The successful RMA applications will enable the US commanders to lift the "fog of war." These are most visible in terms of traditional functions such as intelligence gathering, surveillance, battlefield reconnaissance, and transfer of data and their expeditious communications to subordinates and the use of precision force with maximum accuracy and devastating effect. As Admiral $O$ wens states it: "together, these create the three conditions for combat victory: dominant battle-space knowledge, near perfect mission assignments and immediate/ complete battle-space assessment." ${ }^{11}$

At the systemic level, the declining great power, Russia, and the rising great power, China, challenge the U S primacy. H owever, their challenge is no longer the high level zero-sum and frontal military threats that existed during the Cold War era. Further, a group of regional powers often branded as 'rogue states' has emerged as challengers to the U S-led order, especially in the area of weapons of mass destruction. Soft challenges are prevalent even among allies such as Germany and Canada, especially on questions of nuclear first use and the expansion of NATO. The US seems especially worried that weaker powers would mount "asymmetric challenges" through new tactics and strategies, and by obtaining weapons of mass destruction and long-range delivery systems, including ballistic missiles. Even in the area of RMA technologies, it fears that weaker adversaries could adopt counter-measures in order to "exploit the US military's dependence on large bases, ships and other vulnerable assets, when projecting power overseas, as well as Americans' aversion to suffering casualties." ${ }^{32}$ Further, the U S suspects that anti-U S coalitions may be developing among Russia and China and weaker states with the intention of, at best, extracting concessions from the West.

The US economic dominance is another factor that drives its security behavior. As nations become relatively wealthier in comparison with others, they, just as individuals, wish to keep their prosperity secure from encroachments by external actors, especially if that wealth

30. M ichael $\mathrm{O}$ ' $\mathrm{H}$ anlon, Technological $\mathrm{C}$ hange and the Future of Warfare, Washington D.C.: Brookings Institution Press, 2000:2-3.

31. Admiral Bill O wens, Lifting the Fog of War, N ew York: Farrar Straus Giroux, 2000:99-100.

32. O'Hanlon, Technological Change, 2-3. The interesting historical parallel is the Roman E mpire whose hegemony was challenged and eventually ended by smaller actors. M ichael M ann, The Sources of Social Power, Vol. I, Cambridge: Cambridge U niversity Press, 1986:298. 
is a function of the hegemony arising from dominance in military, technological and normative dimensions. The dominance also results from the fact that the hegemon provides security to allies who in turn support the hegemon's key economic and security goals.

D omestically, the main source of lack of policy change has been the partisan pork-barrel politics and "holy cow" nature of national security among the contending parties. This is clear from debates among the two presidential candidates in the 2000 elections. Both George Bush and Albert Gore want to increase defense spending in order to ward off the threats arising from the so-called "rouge states" and dissatisfied great powers, China and Russia. They advocate increased spending on national missile defense (NMD) and theater missile defense (TM D ) systems even when it is clear to many defense analysts and scientists that such systems are neither cost-effective nor foolproof. But these competing positions come out of a systemic context that the American political elite is attempting to grapple with.

The national security function of the American state has not declined substantially and it is unlikely to decline as long as Washington wishes to remain the global hegemon and as long as its economic and security interests span across the world. The competition for new and better weapon systems and higher allocation for developing cutting-edge technologies are also functions of the US desire to reduce casualties in war and obtain its political and military goals expeditiously if war occurs. Edward Luttwak terms this imperative as arising from "post-heroic warfare," which according to him has replaced the grand style of wars fought for $\mathrm{N}$ apoleanic-type majestic military visions. ${ }^{33}$ This is the most prominent change in the way the security business is conducted. Democracy, mass media, and technology all contributed to the demand for weaponry that would minimize, if not eliminate, casualties.

The continued economic prosperity due to globalization is likely to put pressure on augmenting the U S military strength. Globalization is a source of insecurity for the $U$ nited States, as potential challengers gain technology and wealth generated by the spreading global economic forces. I mprovements in the defense realm by potential adversaries such as China would demand further building up of the American military. An appreciation of the challenges that the hegemonic state

33. Edward N. Luttwak, "T oward Post-H eroic Warfare," Foreign A ffairs, 74(3), M ay/ J une 1995:109-22. 
faces requires a look at the main sources, i.e., other major powers, both declining and rising.

\section{Great Power Challenges to American Hegemony}

The key challenges to American hegemony are likely to come from China and Russia and anti-status quo states/ actors in the developing world. The challenge that R ussia poses to U S hegemony has declined since the days of the Cold War, yet it still remains the most potent power that can decimate the US in a nuclear attack. This Russian capability itself provides the US the incentive to modernize and establish technological superiority in weaponry. The foreign and domestic policies of M ikhail Gorbachev and Boris Yeltsin have been largely failures and as a result Russia has emerged as a weak state in "infrastructural power" and somewhat in terms of "despotic power." Some call it a "messy state." 34 Yet, Yeltsin's successor, Vladimir Putin, has resurrected security as a plank on which to gain popular support and to build strength as a great power nation. Putin's brutal war in Chechnya and his regime's new military doctrine-which gives considerable prominence to nuclear first-use-indicate the revival of a national security state, despite daunting economic and political constraints in doing so. Renewal of nationalism, increased reliance on nuclear strike force, and a strategic alliance with China are central to Putin's plans for increased international standing, while limited accommodations with the West could be pursued through arms control measures in order to buy time and breathing space. ${ }^{35}$

International factors are critical here as well. Two developments involving NATO have shaken the Russian sense of security and are likely to propel it to take a hard-line national security policy. These are the expansion of N ATO into Eastern Europe and N ATO's bombing of Serbia in support of the Kosovar Albanians. The NATO expansion has helped to remove the East European buffer that Russia has

34. Thomas L. Friedman, "The M essy State," M ontreal: The Gazette, O ctober 4, 2000:B3.

35. Thanks to Putin's influence, the Russian D uma in A pril 2000 ratified START II and the CTBT as part of Russia's dual track policy to be conciliatory in arms control so as to gain diplomatic leverage with the US and Europe. $\mathrm{H}$ owever, he has also increased efforts to build next generation nuclear weapons. The Russian effort is to forestall US deployment of NMD and TMD so as to avoid building expensive systems to counter the missile shield. "The O pening Moves in Putin's Game of Chess," Stratfor.com, 24 April 2000. 
enjoyed since World War II. ${ }^{36}$ Russia's security concerns also arise from the competition over resources in East and Central Asia. ${ }^{37}$ Yet, Russia's security can no longer be viewed in geopolitical terms alone. Economic and human security issues, migration of people, ethnic conflicts, threats to uninterrupted energy supply, environmental degradation, organized crime, terrorism, and nuclear smuggling are some non-traditional security challenges Russia continues to face. ${ }^{38}$ In the near-term these challenges will absorb much of Russia's attention, but looming challenges at the systemic level would also remain fundamentally important for this state. And it is unlikely that it will simply stay in the backwaters of international politics.

\section{The Chinese Challenge to US Dominance}

China has emerged as the test case of how a national security state and globalized economic power can go hand in hand. In fact, China has simultaneously adopted both a trading state strategy and a highpitched national security state strategy aimed at making it a leading global power of the $21^{\text {st }}$ century. O ne of the key aims of China to pursue a trading state strategy has been to enhance its power and status in the international system as a major power. Thus, Chinese foreign and security policies in this era of new global social forces are largely driven by traditional realist concerns of power, prestige and territorial security.

China has also increasingly been playing the role of a selective supporter of regional and global institutions, and the norms and principles embedded in them, to the extent that these contribute to China's rise as a full-fledged major power. Sinologists have noticed the evolution of China during the 1980 s as both a "system-exploiting great power" and a "system-maintaining great power," willing to join and utilize international institutions to further its power goals. The change

36. The new national security doctrine published in January 2000 somewhat reflects Russia's deepened security concerns. For the first time since the end of the Cold War, the national security doctrine openly described the West as a "potential threat" to Russia's security. M oreover, with its conventional and military capabilities on the decline, the doctrine called for a nuclear first use "in case of a threat to the existence of the Russian federation as a sovereign state." David H offman, "Russia Acts to Toughen its Security Framework," International Herald Tribune, January 15, 2000:1.

37. I an Bremmer, "Russia's T otal Security," World Policy J ournal, 16(2), Summer 1999:2.

38. Bremmer, "Russia's Total Security," 31-39. 
in China's position on international organizations coincided with "the dramatic rise of China's international standing in the hegemonic world order and its sui generis status as a 'poor global power' can be explained by the change in China's national role conception from a revolutionary system-transforming actor to a neo-realist system-maintaining status quo actor." 39 Becoming a full-fledged global power remains a core national objective of $\mathrm{C}$ hina. Chinese policy makers justify their goal of great power status in order to "prevent the historical humiliations suffered at the hands of Western and Japanese imperialism." 40

Although the People's Liberation Arms (PLA) has reduced its size since 1997, it is still aiming at a "lean, combined and highly efficient army." China's military modernization is increasingly focusing on a 10 -year plan to refurbish its nuclear forces, in order "to make them more accurate, easier to launch and far less vulnerable to attack than they are today. And it is hoping to use high technology to offset its outmoded conventional forces." What China seeks is an arsenal big enough to deter but not so expensive as the Soviet forces that led to M oscow's economic bankruptcy. ${ }^{41}$

\section{The Challenge from Regional Actors}

Fundamental challenges to American hegemony are likely to come from a small group of regional states and sub-national groups that hold asymmetric capabilities, but possess strategies useful to pin down a conventionally dominant power. These include guerilla warfare, terrorism, and the possession, threat of use or actual use of weapons of mass destruction. The U S effort to stem the spread of nuclear, biological and chemical weapons has been motivated by these concerns. This assessment is very much evident in the 1993 Bottom-up Review and the 1997 Q uadrennial Defense Review by the Clinton administration. These reviews called for the US to be prepared to fight and win

39. Samuel S. Kim, "China's International O rganizational Behavior," in Thomas W. Robinson and D avid Shambaugh, eds., Chinese Foreign Policy. Theory and Practice, Oxford: Clarendon Press, 1994:401-34. See also M el Gurttov and Byong-M oo H wang, China's Security: The N ew R oles of the Military, Boulder, Lynne Rienner, 1998; Allen S. Whiting, "Chinese N ationalism and Foreign Policy after Deng," China Quarterly, 142, June 1995:295-316.

40. Paul H. Goodwin, "Force and D iplomacy: China Prepares for the T wenty-First Century," in Samuel S. Kim, ed., China and the World, 4th Edition, Boulder: CO, Westview Press, 1998:171.

41. N ew York Times, M arch 15, 1999. 
two major regional conflicts simultaneously or in close succession in two distant theaters. The US defense efforts since then have been focussed on the regional threats more than anything else. This is evident in the 1998 report to the President and the Congress by Secretary of Defense William Cohen, which concluded that "the foremost regional danger to the US security is the continuing threat that hostile states with significant military power pose to allies and friends in key regions. Between now and 2015, it is reasonable to assume that more than one such aspiring regional power will have both the motivation and the means to challenge US interests militarily." ${ }^{22}$ Terrorist groups that find the U S policies hostile, especially in the $M$ iddle East, are likely to continue their assaults on U S targets in the region.

\section{Soft Security Challenges}

Although not as significant as hard challenges from other great powers and regional actors, soft challenges do matter in the proper management and extension of hegemony. Lesser allies are very much part of the hegemon's strength. When allies loosen their support level or undertake countermeasures, including technological advancements, the hegemonic state's power is challenged in a soft way. The most powerful soft challenges to US hegemony are likely to come from European allies. Having witnessed their ineptitude in Bosnia and Kosovo, they have resurrected the European Security and Defense Identity (ESDI), a soft but symbolically powerful challenge to US hegemony, especially because it threatens the very existence of NATO. The US fears that this initiative may cause the death of NATO altogether as it will have no American representation. ${ }^{43}$ The challenge is also driven by the desire of the European states to maintain their technological edge in aerospace and other cutting-edge areas of innovation. The most significant change in this regard has been the increasing integration of European defense industries unlike during the Cold War period when "for reasons of promoting intra-N ATO rationaliz-

42. Cited in Daniel Goure and J effrey M. Ranney, A verting the D efense Train Wreck in the New Millennium, Washington D.C.: The CSIS Press, 1999:26-27.

43. The decoupling of America from the European security structure has been a concern to American decision-makers. See for example, Madeline Albright, "The Right Balance will Secure NATO's Future," Financial Times, 7 December 1998. 
ation, standardization, interoperability - have long pursued an expanded transatlantic partnership when it comes to armaments cooperation. In the past decade, however, intra-European weapons collaboration and defense industry integration have expanded at a rate that far outstrips transatlantic cooperation.... Western Europe increasingly views the U nited States more as a competitor than a prospective partner when it comes to arms production." 44

Allies and friends of the U S, such as France, now increasingly speak of a multipolar world. Some French policymakers view America is the "hyper power," or the power above the super power status, which needs to be restrained. ${ }^{45}$ The security dimensions of all these are yet to percolate. The U S, if loosened from its hold on NATO and Western Europe, will increasingly focus on technological solutions to solve its security problems. This could generate technological rival ries not just among the US, Russia, and China, but between the US and Europe as well.

\section{Loyalty Rarely Withers Away!}

The view that the state's security function will decline and therefore states will lose the chief rationale for existence is at best premature. As discussed previously, these arguments are based on several illfounded assumptions. They are: first, globalization will remove interstate conflicts and intra-state conflicts, thereby decreasing the role of armed forces. Second, future technology will provide the hegemonic power with overwhelming superiority in offensive, defensive and deterrent capabilities that will make it irrational on the part of the challenger to take on the hegemonic power. Third, geopolitical conflicts are unlikely to occur in the future because Western, i.e. American, military superiority is too high and no new nation is about to catch up with the US. Fourth, ideology, nationalism, etc., will increasingly become irrelevant as the benefits of globalization spread throughout the world. $\mathrm{N}$ ations and individuals being rational will embrace the virtues of globalization, or they will simply be constrained by the mighty forces unleashed by globalization. Finally, state-society tensions will increase in the absence of identifiable external threats as antistatist forces will gain an upper hand.

44. Richard A. Bitzinger, "G lobalization in the Post-C old War D efense I ndustry: Challenges and Opportunities," in M arkusen and Costigan, eds. A rming the Future, 321 and 325.

45. H ubert Verdine, Les Cartes de La France, Paris: Fayard, 2000:9. 
These assumptions are problematic. First, a challenger can design asymmetric responses to counter the dominant state's power position. These include guerrilla warfare, terrorism, and options such as cyberwar or technological shortcuts. Second, technology itself is a cause for conflict because introduction of new technologies can often increase the offensive power of states that gained early access to them. The industrial revolution gave railroads, which enabled key European states to organize mass movements of troops and launch popular mobilization. The rise of the automobile, aircraft, and aircraft carriers improved the offensive capabilities of states that acquired or mastered these technological innovations early on. The nuclear revolution increased the power of the deterrent and, to some extent, defense. We still do not know how the information revolution is going to affect warfare, whether it will result in advantage for the offense, defense or deterrent. If it helps the offense, conflict behavior of the beneficiaries of the information revolution is prone to increase.

Finally, geopolitical conflicts often arise as a result of an unintended consequence of differential growth rates. A state that makes major gains in economic and military capability may attempt to gain a leadership role internationally. As the international system has no peaceful mechanism to allow peaceful transitions, the likelihood of conflict is very much present in the system.

All these elements point to the issue that loyalty is likely to stay with the nation state. Differential growth rates imply that different states provide benefits to the citizens in varying rates. In the example of the U S, loyalty is a function of the U S hegemony, which is largely the reason why Americans enjoy a higher standard of living compared to citizens of other nations. The loyalty to the state is thus very much intertwined with the individual's own interests in seeing this hegemony prolonged as long as possible. Any serious challenge to the American hegemony is likely to spark the individual's sense of nationalism, often claimed to be decreasing at the altar of global forces.

With respect to state-society relations, it is often argued that, in the absence of a grave external threat, the cohesiveness of the state will decline, as anti-statist forces will emerge powerful. H owever, this argument assumes that the state elite mismanages foreign policy as it did in the 1960s, that democratic institutions are poorly designed to incorporate change and that the civil society has weak roots. As Friedberg argues, although the threat of war produced pressures to build a powerful central state in the US, they were counterbalanced 
by "strong anti-statist influences that were deeply rooted in the circumstances of the nation's founding." He adds: "The proper balance between statist and anti-statist impulses can sometimes be attained in the American system through convergence and coolly reasoned compromise; more often it will be the product of heated debate and intense, often bitter struggle." ${ }^{46} \mathrm{M}$ y sense is that the end of the Cold War has not yet produced a situation whereby anti-statist forces have gained dominance, as the balance in terms of the role of the state is visible in both the Republican and the Democratic parties. The anti-statist forces within the Republican Party in fact are stronger proponents of national defense, a contradiction of sorts.

\section{Conclusions}

Several conclusions emerge from this analysis. First, globalization has not ended the core security functions of nation-states, even though some states have scaled back on military spending. Second, globalization is occurring in the backdrop of a near unipolarity in the structure of the international system in which the hegemonic power, the US, is the leader of the process. This structural condition has been strengthened by the increased role of US corporations, while these corporations themselves make use of the American power position to reinforce their economic and political roles across the world. Third, the new security threats have not made states redundant. The major innovation of states has been the inclusion of the new security threats, such as environment, disease etc., into national security calculations.

Fourth, state responses in the sphere of security have not been uniform across cases or regions. Global social and economic forces have affected states in varying degrees. The uneven responses in the security arena in the face of these new global forces are due largely to the varying contexts of states. $M$ ajor powers have reduced the level of conflict since the end of the Cold War, but security competition exists in terms of political influence and weapons innovation. Although several regional conflicts have subsided, traditional security concerns still dominate the behavior of key regional states.

For the U nited States, the global hegemon, military power bestows certain key functions. Its role as the extant global protector provides it with a degree of social-structural power over allies and coercive

46. Aaron L. Friedberg, In the Shadow of the Garrison State, Princeton: Princeton U niversity Press, 2000:3-4; 351. 
power over adversaries. The status a protector gains from anticipated as well as undefined threats is thus a powerful source of control and collaboration for the $U$ nited States. In a more negative sense, it does allow it to control the periphery-those states yet to be co-opted fully in the hegemonic order - that could chip away at the dominant status of the hegemonic power. The US is likely to remain a national security state par excellence, although it may increasingly fashion technological solutions to gaining dominance over allies and adversaries and avoiding casualties in active military confrontations. The US hegemony as a systemic condition guarantees adversarial responses from subordinate actors most affected, even when the US elite devises strategies to guarantee that the hegemonic power remains preponderant over all other large and small challengers.

Revolutionary changes in military technology are a crucial factor that will determine how states will provide security or respond to security threats in the future. States tend to worry about technological breakthroughs as the political, military and economic gains of such changes may help transform the state or society that acquire the cutting-edge technology disproportionately. Technology also partially determines how a state organizes its resources for military security as well as what strategies and doctrines it will adopt. The type of weapons and technology dictated to a certain extent the adoption of strategies such as the blitzkrieg and offensive doctrines before World War I and II by European states. ${ }^{47}$ Thus, the relationship between technology and military strategy is an enduring one and it will continue into the future inter-state and intra-state relations.

Finally, states tend to adapt to changes in technology and sociopolitical environments in varying degrees. States assume new organizational means to deal with challenges posed by external and internal changes. Some states may innovate rapidly and may succeed in providing security through means other than military/ coercive instruments. Military/ coercive instruments are one of several mechanisms states possess to provide security and therefore it is incorrect to assert that states have lost their power in the security realm in the era of globalization. Successful adaptation to new global social forces is a sign of strength of the nation-state, not its weakness.

47. O 'H anlon, Technological Change and the Future of Warfare 


\section{Content}

Contending Views on Globalization and the State 7

Responses by the U nited States 19

Great Power Challenges to American H egemony 25

The Chinese Challenge to US Dominance 26

The Challenge from Regional Actors $\quad 27$

Soft Security Challenges $\quad 28$

Loyalty Rarely Withers Away! 29

Conclusions 31 